Oskar Meller

Wydział Filologiczny, Uniwersytet Wrocławski

\title{
Ginsberg Barańczaka. Z dziejów jed(y)nego przekładu
}

W szkicu o Barańczakowych paratekstach poprzedzających wybory przekładów poetów anglosaskich Jerzy Jarniewicz [2018: 152] nazywa Barańczaka szaradzistą pochylającym się nad oryginałem niczym nad logiczną krzyżówką, zarazem krytycznie definiującym własną strategię translatorską właśnie w owych „wstępniakach”, pozornie niesamodzielnych, plasujących się na marginesie twórczości. Barańczak [2001: 9-10] we wstępie do Wyboru poezji Jamesa Merrilla pisał: „Tymczasem wymienić z żyjących poetów amerykańskich Ginsberga a nie zauważyć Merrilla to trochę tak, jakby ktoś dzisiaj chwalił Jewtuszenkę a nie wiedział nic o Brodskim”. W tym niezwykle ekonomicznym, dubeltowym przeciwstawieniu twórców znanych i uznanych, jednoznacznie negatywny stosunek autora Chirurgicznej precyzji do poezji Allena Ginsberga odbija się chyba najwyraźniej. Poeci egotyczni, zadufani nigdy nie byli dla Barańczaka poetami zaufanymi. W perspektywie poetyckiego projektu, czy samej postawy artystycznej, Ginsberg reprezentuje stronnictwo, które Barańczak konsekwentnie neguje. Naturalnie więc poszukiwanie punktów stycznych w poetykach obu bohaterów niniejszego szkicu byłoby sporym nadużyciem. 
Również w tekstach krytycznych i esejach Barańczaka odwołań do apostoła bitników jak na lekarstwo. Jeżeli autor White Shroud już się pojawia, to jedynie jako przeciwwaga dla tego, co Barańczaka w poezji anglosaskiej warsztatowo fascynuje, czy też zajmuje akademicko. Najbardziej esencjonalnym przykładem pozostaje tu fragment z Małego, lecz maksymalistycznego manifestu translatologicznego towarzyszący analizie przekładowych pułapek wiersza Stopping by woods on a snowy evening Roberta Frosta:

Miałoby się przecież prawo przypuścić, że po Central Parku poezji naszej epoki tłumacz może się przechadzać krokiem swobodniejszym i w stroju bardziej niedbałym niż po wersalskich ogrodach dawniejszych obszarów tradycji. Otóż wcale tak nie jest. Nie jest w każdym razie wtedy, gdy upodobania wiodą nas w stronę tych poetów dwudziestowiecznych, którzy, zamiast przejeżdżać alejkami swojego Central Parku na hałaśliwych deskorolkach i motorowerach, wolą przysiąść na ławeczce i wdać się z nami w rozmowę. Jako tłumacza interesują mnie właśnie spotkania $\mathrm{z}$ takimi poetami - poetami dialogu, nie Ginsbergowskiego „skowytu” i nie niedosłyszalnego szeptu wielu dzisiejszych solipsystów. [Barańczak 1994: 57]

Skoro Ginsberg zostaje tu przeciwstawiony Frostowi - jednemu z autorów, który miał największy wpływ na poznańskiego nowofalowca - to ten pierwszy utożsamiać musi w powyższym zestawieniu to, co w amerykańskiej poezji „naszej epoki” Barańczaka mierzi. W przełomowym dla Frosta North of Boston najważniejsze poematy (Śmierć najmity, Domowy pochówek) zostały zdialogizowane, a on sam ujawnia się w nich jako poeta rozmowy, o którą na ławce w Central Parku upomina się Barańczak tłumacz. Tymczasem Ginsbergowski „skowyt” to przecież autotematyczny, egotyczny monolog, podobnie jak większość lirycznych narracji bitnika z lat 50. i 60., wyznaczających główne tendencje poetyki beat. W działalności przekładowej Barańczak - podążając za własną metaforą - podczas spaceru przez Central Park najnowszych amerykańskich tradycji konsekwentnie omija alejki pełne „skowyczących” deskorolkarzy. Stąd też - jak słusznie wskazuje Jarniewicz 
[2018: 174] w szkicu będącym postrecenzją antologii Od Walta Whitmana do Boba Dylana - w tak obszernej i bogatej spuściźnie translatorskiej nie uświadczymy wielu prób mierzenia się tekstami naczelnych bitników: „Wśród Barańczakowych twórców nie ma Kerouaca, Syndera, Corso, Ferlinghettiego, Baraki”. Barańczaka cechowała niechęć nie tylko do samego Ginsberga, jego gestów poetyckich, autokreacji i postawy artystycznej, ale także, jak się wydaje, jeszcze większa - do krajowych prób mierzenia się z jego tekstami. Kiepskim tłumaczeniom Grzegorza Musiała, zawartym w antologii Ameryka! Ameryka!, autor Atlantydy poświęcił niezwykle ironiczne, lecz precyzyjne krytycznie omówienie opublikowane w „Tygodniku Powszechnym”, w którym brutalnie obnaża rażące translatorskie buble. Z kolei w szkicu Ten staroświecki Ginsberg Piotr Sommer [2018: 30o] określił środowiskowe przyjęcie Musiałowskich przekładów jako „krytyczną młócką, z której tłumacza w ciężkim stanie odwiozło pogotowie”. W tym samym tekście zastanawia się również, czy za niezbyt przychylnym odbiorem Ginsberga na naszym podwórku, prócz jego tytułowej anachroniczności (dotarł do nas z opóźnieniem), nie stoi fakt, że teksty najistotniejsze dla twórczości nowojorczyka, reprezentatywne dla jego frazy, nie doczekały się nigdy rzetelnych przekładów na język polski [Sommer 2018: 30].

Po poematy najbardziej znane, najmocniej w kulturze osłuchane: Skowyt, Kaddysz, Ameryka, z miernym skutkiem sięgali wspomniany już Musiał czy Bogdan Baran. Po przeciwnej stronie ustawili się tłumacze szukający Ginsberga alternatywnego, zmieniającego profetyczny ton narkotycznych wizji na cichą medytację, ekonomiczny imagizm. Na marginesy twórczości autora Gates of Wrath - w wyborze Znajomi z tego świata zredagowanym przez Sommera - udają się Julia Hartwig i Artur Międzyrzecki. Poszukują raczej obiektywistycznych klisz z Williama Carola Williamsa czy Charlesa Reznikoffa, patronackich odniesień do poetyckich mistrzów tłumaczonego niż świadectw jego kontrkulturowych akcesji. Mimo bliźniaczej Barańczakowi niechęci do Ginsberga buntownika z jego sztandarowych poematów, wspomniany już Sommer czy Andrzej Szuba znajdują we frazie Amerykanina struktury godne translatorskiego trudu. W antologii Od Walta Whit- 
mana do Boba Dylana Barańczak zamieszcza tylko jeden przekład z twórczości autora Pull my Daisy. Dlaczego właśnie A Supermarket in California? We wspomnianej antologii zestawy chronologicznie przedstawianych amerykańskich poetów poprzedzają krótkie notki biograficzne napisane przez tłumacza. W tej poświęconej Ginsbergowi za najwybitniejszy utwór bitnika Barańczak uznaje poemat Kadysz, stanowiący jego zdaniem interesującą, a przede wszystkim zaskakująco udaną próbę oderwania się od - będącego tu niewątpliwym wzorcem - poematu Charlesa Reznikoffa $\mathrm{z}$ książki Going to and fro and walking up and down. Barańczak ubolewa również, że przez rozmiary Kadyszu nie znalazł dla niego miejsca w swoim wyborze. Moglibyśmy zatem przypuszczać, że Supermarket $w$ Kalifornii zajmuje drugie miejsce na Barańczakowej liście „ulubionych kawałków” autora Plutonian ode. Zaskakujące, że wybór pada na wiersz z tomu Howl and the other poems, a więc z najbardziej „skowyczącego” okresu w twórczości poety z Newark. Jednak - co mogło u Barańczaka doprowadzić do anegdotycznego ukłucia w kręgosłupie - to jeden z nielicznych wierszy-rozmów wczesnego Ginsberga, w którym poeta wyraża wysoką świadomość własnej poetyki przez apostroficzne zwroty do jednego ze swych patronów, ojca poezji amerykańskiej: Walta Whitmana. Jeżeli zatem Barańczakowi tłumaczowi chodzi o dialog z przekładanymi poetami, również rozmowę między nimi, to właśnie w Supermarkecie... łatwo tę wymianę myśli lokalizuje, w dodatku $\mathrm{w}$ formie pozwalającej osadzić oryginał $\mathrm{w}$ jego rodzimej tradycji poetyckiej w sposób satysfakcjonujący Barańczaka krytyka.

Sytuacja poetycka jest w tym wierszu stosunkowo przejrzysta. Podmiot przemierza alejki jednego z rozjarzonych neonami kalifornijskich supermarketów. W tej odysei między sklepowymi półkami towarzyszy mu duch Whitmana, na moment pojawia się również widmo Federica G. Lorki. Oczywiście mówiący w tym wierszu to sam Ginsberg, co potwierdził przy okazji jednego ze sfilmowanych odczytów tekstu, podkreślając, że opisana nocna wycieczka po mleko miała miejsce w rzeczywistości. Ginsberg upodabnia układ i prozodię tego utworu do miary Whitmanowskiej, analogicznie jak w tekście Napisane $w$ moim śnie przez W.C. Williamsa zbliżał strukturę wiersza do charakterystycznej 
ekonomii strof autora Sour Grapes. Zatem podstawowym gestem bitnika w jego świadectwach powinowactwa przejawiających się w tradycji będzie adaptacja i trawestacja poetyk własnych mistrzów. Naturalnie więc A Supermarket in California napisany jest wierszem wolnym, nieregularnym, wymykającym się klasycznie zrytmizowanym formom. Bill Morgan [2006: 206] zauważa, że również wydłużenie klauzul wersowych stanowi w tym utworze gest poetyckiego pokrewieństwa z dykcją autora Dzieci Adama. Ta Whitmanowska „długowersowość” najczęściej ujawnia się u Ginsberga w dłuższych formach.Najobszerniejsze klauzule znajdziemy w poematach Sunflower Sutra, Beginning of a Poem... czy Thoughts Sitting Breathing. Ten ostatni, z tomu Mind breaths all over the place, można z pewnością uznać za swoisty manifest poetyki, o jakim autor pisał w kontekście konstrukcji równie obszernych wersów ze Skowytu. Nazywał to „fizyczno-mentalną inspiracją myśli zawartą w elastycznym oddechu” [1959: 132]. Według tego systemu prozodycznego jeden wers w wierszu miał się równać dokładnie jednemu oddechowi poety. Choć sam Ginsberg [1959: 133] poświadczał, że jego oddech trwa bardzo długo, to poemat Supermatket $w$ Kalifornii wydaje się niemożliwy do odczytania w tych konwencjach. Martina Pfeiler, zastanawiając się nad tą kwestią, zderza ze sobą dwie sprzeczne linie argumentacji. Z jednej strony możemy bowiem uznać, że wersy Skowytu i Kadyszu, odczytywane przez autora z powodzeniem „na jednym oddechu”, stanowią konstrukcje trudniejsze fonetycznie. Jednak z drugiej strony nie bez powodu te najdłuższe wersy Supermarktu... (zdaniem Pfeiler najbardziej whitmanowskie) poeta poprzedza akapitem - miejscem na oddech - od czego stronił we wspomnianych, najbardziej ikonicznych tekstach [Pfeiler 2003: 132]. Unikał tego również sam Whitman - takich wcięć w otwarciu strofy nie znajdziemy w żadnym z wierszy ojca amerykańskiej liryki. Mimo tej różnicy zwrotki Supermarketu..., przynajmniej wizualnie, przywołują układy z Begginers czy Once I Pass'd through a Populous City.

Whitman i hołd, jaki składa mu Ginsberg w swoim wierszu, zdecydowanie pozostają centralnymi motywami tego utworu, organizującymi to, co „dzieje się” w tekście. Takie podejście góruje w przekładzie Sommera, który rygorystycznie odwzorowuje ory- 
ginalny układ strof. Czy skoro wersyfikacja poematu stanowi dla Ginsberga ukłon w kierunku ojca wiersza wolnego, to także w przekładzie Barańczaka właśnie układ wersów pełni funkcję dominanty semantycznej? Z tej perspektywy już samo otwarcie utworu poświadcza dość przewrotne stanowisko tłumacza:

What thoughts I have of you tonight, Walt Whitman, for [I walked down the sidestreets under the trees with a headache [self-concious looking at the full moon.

In my hungry fatigue, and shopping for images, I went into [the neon fruit supermarket, dreaming of your enumarations! What peaches and that penumbras! Whole families

[shopping at night! Aisles full of husbands! Wives in the avocados, babies [in the tomatoes! --and you, Garcia Lorca, what were you doing by the

[Ginsberg 2009: 144]

[watermelons?

Co za myśli o tobie nachodzą mnie dziś wieczór, Walcie

[Whitmanie!

albowiem błądziłem cały ten wieczór pod drzewami bocznych ulic, z bólem głowy i poczuciem własnej nienaturalności popatrując na księżyc w pełni

W zgłodniałym znużeniu, rozglądając się za obrazami, [wkroczyłem w neonowy supermarket z owocami i zaczęły mi się śnić enumeracje!

[twoje To brzoskwinie! te półcienie! Całe rodziny na wieczornych [zakupach! Tłumy małżonków w przejściach między półkami! Małżonki w owocach avocado, niemowlęta w pomidorach! - a ty, 
Lorca, co tam robiłeś w pobliżu góry arbuzów?

[Barańczak 1998: 229]

Barańczak nie tworzy lustrzanego odbicia, usuwa przerwy na oddech z nagłosów otwierających strofy, wprowadza je we frazach wewnętrznych, maksymalizuje $w$ wygłosie, przesuwając ostatnie słowa z otwarcia linijki do jej zakończenia. Zaszły tu również zmiany ilościowe: zwiększyła się liczba wersów w każdej z partii poprzedzonych akapitem. $\mathrm{Z}$ pewnością część tych modyfikacji wymusily względy językowe, potrzeba doprecyzowania, czy też rozpisania fraz niejasnych w polszczyźnie. W ten sposób avocado zostało „owocem avocado”, headache self-concious przeszło w „poczucie własnej nienaturalności”, a nieokreślona ilość arbuzów z wersu ostatniego stała się ich "górą" w analogicznym fragmencie przekładu. Zdawałoby się, że tak duże zmiany w samym układzie tekstu wskazują na zerwanie tłumacza $\mathrm{z}$ dominantą semantyczną ujawniającą się w strukturze wiersza. To odstępstwo od hołdującego Whitmanowi wizualnego układu wiersza Ginsberga nie przesądza o zerwaniu z dominantą whitmanowską w Barańczakowym przekładzie. Wręcz przeciwnie, tłumacz cyzeluje te patronackie koneksje, zbliża obu poetów, poprawia po bitniku, jeszcze wyraźniej „whitmanizuje” układ Supermarketu $w$ Kalifornii. Można zgłosić tu pewien sprzeciw, bowiem poeta z West Hills nigdy nie rozpoczynał wersu od pauzy na oddech, nie justował wygłosu strofy do prawego marginesu. Natomiast Barańczak zmienia to również $\mathrm{w}$ swoich tłumaczeniach autora Shut not your doors, zawartych w tej samej antologii co analizowany przekład z Ginsberga. Jednak tym, co najbardziej kłóci się prozodycznie ze strofą Whitmanowską, pozostaje Ginsbergowskie miejsce na oddech w nagłosie, które tłumacz słusznie usuwa.

Patronat ojca amerykańskiej poezji ujawnia się również w budowaniu najdłuższego wersu utworu wokół zwróconej do niego apostrofy. Wiele z własnych wierszy twórca postaci Jacka Englesa oparł właśnie na tej figurze. Apostrofy pojawiają się już w samych tytułach tak znanych liryków, jak Do stanów, Do ciebie czy Poeci przyszłości. Ten ostatni w oryginalnej formie rozpoczynają słowa: „Poets to come! Orators, singers, musicians to come!” 
[Whitman 1992: 28]. Kluczowe pozostaje tu wykrzyknienie, w tym przypadku podwójne, niemal zawsze towarzyszące apostrofom we frazie Whitmana. Ginsberg, hołdujący w Supermarkecie... swojemu patronowi, adaptujący apostroficzną budowę jego długich wersów, zapomina o pewnym szczególe, niezwykle istotnym w kontekście próby graficznego odtworzenia zwrotek Whitmana: brakuje w nich właśnie wykrzyknika. W przekładzie Barańczak znów cyzeluje, wstawia pozornie nieistotny znaczek na końcu bezpośredniego zwrotu do ducha amerykańskiego wieszcza, zawiązuje whitmanowską dominantę thumaczenia.

Co, obok ducha Whitmana, robi w kalifornijskim supermarkecie widmo Lorki? Samego autora Śpiewaka cygańskich romansów poetycko z Ginsbergiem łączy, jak się wydaje, jedynie wpadanie $\mathrm{w}$ tony surrealistyczne. Z Whitmanem natomiast jeszcze mniejchyba że weźmiemy pod uwagę miejsca, jakie autorzy odpowiednio zajmują w kanonie poezji swoich krajów. Glen Burns znajduje jednak dość oczywistą kategorię łączącą całą trójkę poetów, mianowicie homoerotyczny ton ich twórczości, podmiot projektujący świadectwa seksualnego wyzwolenia. Ponadto możemy przypuszczać, że Lorca zostaje tu przywołany konkretnie ze swoimi poematami nowojorskimi jako obcy świadek, zewnętrzny obserwator Ameryki epok dwóch nowojorczyków. Według Burnsa wyzwolona, witalistyczna miłość w ujęciu trzech wspomnianych autorów pochodzi z rejestru uczuć całkowicie antagonistycznych względem tego, co w ikonosferze reprezentuje współczesny Ginsbergowi supermarket [Burns 1983: 19].

W tym miejscu rysuje się kolejna linia interpretacji Supermarketu w Kalifornii. Burns [1983: 118-119] widzi w tym utworze przede wszystkim hipisowskie świadectwo antykapitalistycznego sprzeciwu wobec globalizacji, którą utożsamia sklepowy moloch. Ginsberg przyznawal, że w jego frazie patronat autora Tataraku wyraźnie wpłynął na sposób manifestowania seksualności podmiotu. Własne preferencje i sposób rozumienia terminu love uważał za zbieżne $\mathrm{z}$ Whitmanowskim poglądem na najwyższą z Platońskich cnót [Morgan 2006: 222]. Homoerotyzm poetyckiej kreacji rzeczywistości u obu autorów, również u Lorki, zdaniem Byrne’a R.S. Fone’a [2001: 706] wyraża rodzaj specyficznej 
energii seksualnej, która miałaby służyć ludziom do konstytuowania „poczucia własnej normalności” sprawniej i precyzyjniej niż filozofia. Tytułowy supermarket, kapitalistyczny gigant wraz z przechadzającymi się po jego alejkach „małżonkami”, matkami uganiającymi się między półkami za swymi dziećmi, utożsamia wszystko, co antagonistyczne wobec Whitmanowskiej filozofii wolnej miłości. „Wolność” obok „równości” jest zresztą kategorią, którą Jarniewicz [2018: 170], pisząc o Barańczaku tłumaczu, nazywa „istotą amerykańskiego etosu”: jednocześnie dominantą wyboru i kształtu przekładów tworzących amerykańską antologię z 1998 roku. Ginsberg, przywołując ducha ojca wiersza wolnego, zestawia więc Amerykę z jego poematów, w której od lat obywatele najchętniej się przeglądają, z tą, którą jego następca zastał w jednym z supermarketów w Berkley w 1955 roku. Uczucie, jakie towarzyszy mówiącemu w owym komparatystycznym zestawieniu ojczyzny naznaczonej pamięcią wojen domowych, światowych, konfliktu wietnamskiego, z ojczyzną idylliczną, współczesną poematom Whitmana, nieco ponad oryginalnym tekstem Supermarketu..., tłumacz wydaje się celnie parafrazować. Mówiącego zostawia natomiast $\mathrm{z}$,poczuciem własnej nienaturalności”.

Barańczak semantycznie modyfikuje jednak w tej strofie niewiele, jedynie dopisuje, nie skraca, nie szuka ekwiwalentów.Fone [2001: 709] słusznie wskazuje, że Whitmanowski sznyt rzeczywistości kreowanej w poemacie Ginsberg opiera na homoerotycznym napięciu w relacji mówiącego, zbliżonym do „wolnomiłościowych" wersów patrona. Obiektem seksualnej obserwacji są tutaj ekspedienci supermarketu, chłopcy, utożsamiający witalną siłę, niewinność, anielskie piękno. Z tymi przymiotami chłopięcej młodości Ginsberg konfrontuje starość obserwatora - samotnego, bezdzietnego człowieka. Naturalnie więc relacja ta przypomina nie tylko zażyłości między późnym Whitmanem a adresatami jego erotyków, ale także pojawiające się w utworach należących do kanonu prozy europejskiej, napięcie pomiędzy bohaterami Mannowskiej Śmierci w Wenecji czy - bliżej naszego podwórka - „trans-atlantyckie" awanse Gonzalo w kierunku Ignacego. O ważkości tej sceny oglądanej z perspektywy homoerotycznego hołdu, jaki Ginsberg składa w kierunku miłosnej filozofii Whitmana w ana- 
lizowanym tekście, świadczy umiejscowienie jej w pierwszym dwuwierszu drugiej strofy, tuż obok kolejnej apostrofy do autora I Sing the Body Electric.

I saw you, Walt Whitman, childless, lonely old grubber, [poking among the meats in the refrigerator and eyeing the grocery [boys. I heard you asking questions of each: Who killed the pork What price bananas? Are you my Angel? [chops? I wandred in and out of the brilliant stacks of cans following [you, and followed in my imagination by the store detective. We strode down the open corridors together in our solitary [fancy tasting artichokes, possessing every frozen delicacy, and [never passing the cashier.

[Ginsberg 2009: 144]

I zobaczyłem ciebie, Walcie Whitmanie, bezdzietny, [samotny, stary gmeraczu, jak myszkujesz w zamrażalnikach z mięsem [i obmacujesz spojrzeniami chłopców z obsługi. Słyszałem, jak każdemu z nich zadajesz pytania: Kto [uśmiercił ten schab wieprzowy? Po ile banany? Czy jesteś moim Aniołem? Wędrowałem po sklepie twoim śladem, wchodząc [i wychodząc spomiędzy olśniewających stosów puszek, sam śledzony, jak [sobie wyobrażałem, przez sklepowego detektywa.

Nasza samotnicza fantazja wiodła nas razem otwartymi na [przestrzał korytarzami i próbowaliśmy smaku karczochów albo 
[wchłaniali najróżniejsze mrożone specjały, nie przechodząc w ogóle przez kasę.

[Barańczak 1998: 230]

Tym razem tłumacz rezygnuje z wykrzyknienia towarzyszącego apostrofie. To gest naturalny, jeśli weźmiemy pod uwagę, że w strofie pierwszej podmiot przyzywa ducha Whitmana, rozpoczyna dialog z mistrzem, podczas gdy w otwarciu drugiej zwrotki prowadzi z nim już dalszą rozmowę, dialog trwa. Znów Barańczak usuwa miejsca na oddech w nagłosie najdłuższych wersów. "Whitmanizacja” struktury poematu jest zatem konsekwentnie prowadzona w jego dalszej części. Ponownie nie udaje się autorowi Korekty twarzy zachować pierwotnej liczby wersów, rozwija idiomy, rozpisuje zwroty niemożliwe do oddania w polszczyźnie z zachowaniem ich ekonomii. W ten sposób eyeing przechodzi $\mathrm{w}$ „obmacywanie wzrokiem”. Trudno o spolszczenie tego orzeczenia umiejętniej wpisujące się w homoerotyczne napięcie, dominujące w rzeczywistości wykreowanej w poemacie.

W układzie ostatniej strofy Barańczak również „poprawia” po Ginsbergu świadectwa patronatu, wzmacnia formalne gesty Whitmanowskiego powinowactwa, cyzeluje klauzule, usuwa wcięcia $\mathrm{w}$ nagłosie najdłuższych linijek. Apostrof, tym razem w formie pytania, umieszczony zostaje, zgodnie $\mathrm{z}$ oryginałem, $\mathrm{w}$ centrum najdłuższej klauzuli. Zatem najistotniejsze prozodycznie frazy pozostają na swoich miejscach, mimo że pierwotna liczba wersów znów zostaje naruszona, czego po raz kolejny nie pozwala Barańczakowi uniknąć przekład pewnych idiomów i zwrotów bardziej ekonomicznych w angielszczyźnie, na szerzej „rozpisane” w ojczystym języku tłumacza. Semantycznie jednak Barańczak modyfikuje niewiele, nie wymienia figur, nie synonimizuje, pozostawia poetyckie obrazy oryginału niemal nienaruszone.

Where are we going, Walt Whitman? These doors close in [an hour.

Which way does your beard point tonight?

(I touch your book and dream of our odyssey in the 
feel absurd.)

[Supermarket and

Will we walk all night through solitary streets? The trees add [shade to shade, lights out in the houses, we'll both be Lonely. Will we stroll dreaming of the lost America of love past blue [automo-

biles in driveways, bone to our silent cottage?

Ah, dear father, graybeard, lonely-old courage-teacher, what

[America

did you have when Charon quit poling his ferry and you got

[out on a smoking bank and stood watching the boat disappear on the [black waters of

Lethe?

[Ginsberg 2009: 144]

Dokąd zmierzamy, Walcie Whitmanie? Za godzinę

[zamykają. Jaki

kierunek wskazujesz sterczącą brodą?

(Dotykam twojej książki i widzę jak we śnie naszą

odyseję i odczuwam własną absurdalność.)

[supermarketową

Czy będziemy się błąkać przez całą noc po osamotnionych

[ulicach?

Drzewa kładą cienie na cieniach, światła w domach pogasły,

[będziemy

obaj samotni.

Czy w drodze do domu, do naszej cichej chatki, będziemy

[kroczyć przed

siebie, śniąc o utraconej krainie miłości, Ameryce, i mijając błękitne samochody na podjazdach?

Drogi ojcze, siwobrody i samotny nauczycielu odwagi, czym

[była twoja

Ameryka, gdy Charon na promie odłożył drąg i wydostałeś się na brzeg, i stałeś w oparach mgły, patrząc jak odpływająca 
lódź znika na czarnych wodach Lety.

[Barańczak 1998: 230]

Pierwsze sześć wersów uznać możemy za przekład „dosłowny”, bezpośredni, o którym pisał Barańczak [1994: 107] w szkicu dotyczącym polskich tłumaczeń poezji Gerarda Manleya Hopkinsa jako o wiernym, lecz kompletnie nieekonomicznym. We wskazanym fragmencie Supermatketu... sam podważą tę tezę i z wyjątkiem delikatnych przesunięć niemal zachowuje oryginalną liczbę wersów przy zbliżonym układzie klauzul. Nie mieści jedynie frazy „obaj samotni”, która ląduje w wygłosie wersu siódmego, co oczywiście stanowi dodatkowe zaakcentowanie wpływów Whitmana. Druga część strofy również rozrasta się tylko o jeden werset. Jednocześnie w ostatnim z nich Barańczak rozwija wygłos pierwowzoru. Na początku klauzuli osamotniona fraza Lethe $\mathrm{u}$ Ginsberga płynnie wchodzi po kończącym poprzedni wers black waters of. Barańczak, zgodnie z kompozycją całego przekładu, przenosi nazwę mitologicznej rzeki do wygłosu, gdzie bez nadbudowania orzeczeniem zginęłaby po nienaturalnej, wydłużonej pauzie.

W Supermarkecie... symptomatyczny pozostaje układ zdań $\mathrm{w}$ konkretnych wersach. Whitman także wiele ze swoich strof rozpoczynał od pytań, często gdy tytułem wiersza czynił incipit (Jakie miejsce jest oblężone?; To ty jesteś tą nowa istota, która ma się ku mnie?). Te sekwencje prezentują go jako poetę rozmowy. W poemacie Ginsberga pytanie stanowi również wygłos całości, domknięcie ostatniej klauzuli, choć bez pytajnika na jej końcu. Tłumacz naturalnie zachowuje ten szyk. Podmiot pyta, jaki był jego kraj przed „niebieskimi automobilami”, gdy pieśniami opiewał go jeszcze autor Śmierci weterana. Finał ostatecznie ustanawia leitmotivem Supermarketu w Kalifornii Amerykę czasów „samotnego nauczyciela odwagi" i sen jego poetyckiego lennika o istocie tej „amerykańskości”.

W Barańczakowych antologiach poezji anglosaskiej nie znajdziemy więcej przekładów z autora Wichita Vortex Sutra. Jak pisał Jarniewicz: próżno szukać tam także innych bitników, choćby tych znanych głównie ze sztuki poetyckiej: Gregory’ego Corso czy Petera Orlovsky'ego. Równie marginalnie Barańczak traktuje 
Ginsberga w swoich paratekstach. Jeżeli już przywołuje nowojorczyka, to jedynie w antypatycznych dla niego starciach z Frostem czy Merrillem, aby zantagonizować poezję Allena z tekstami autorów, których w przekroju xx-wiecznej liryki amerykańskiej tłumacz ceni, uznaje za wartych krytycznej i translatologicznej uwagi. Nie sposób wyrokować, czy pojawienie się jed(y)nego tłumaczenia Ginsberga w zbiorze z 1998 roku wiąże się z ciepłym stosunkiem Barańczaka do Supermarketu $w$ Kalifornii, czy jedynie ze świadomością, niezależnej od personalnych sympatii tłumacza, wpływowości poetyckiego skrzydła ruchu beat na „skowyczących” naśladowców autora Laughing gas, czy obrazu poezji amerykańskiej lat 6o. i 70. poza granicami Stanów Zjednoczonych. Wybór tego poematu mniej przypadkowy wydaje się, gdy spojrzymy na przekrój całej antologii. Nie chodzi tu wyłącznie o wymienienie ojca wiersza wolnego już w samym tytule tomu, choć oczywiście jest to jeden z podstawowych tropów.

Skoro za Jarniewiczem możemy przyjąć, że jedną z kategorii scalających wszystkie teksty wyboru jest łączący je ton demokratycznej proklamacji idei amerykańskiej „wolności”, to wśród poetów trudno o jej orędownika zagorzalszego od Whitmana. Choć Supermarket... pochodzi z tego samego tomu co najbardziej wpływowy z poematów Ginsberga, opiera się na tym samym ,jednooddechowym" rytmie i konstrukcji wydłużonych klauzul, to można zaklasyfikować go do części tekstów „nieskowyczących” jak powiedziałby Barańczak - rezygnujących z krzyku na rzecz dialogu. Zatem tym, co należało w przekładzie tego poematu ocalić, był dla tłumacza idiom rozmowy. Ten gest osadza poetę na linii wpływów bezpośrednio, bo za pomocą apostrof skierowanych do ojca poezji amerykańskiej. Podobne korzenie ma również organizacja układu strof Supermatketu..., hołdująca strukturze wielu tekstów wieszcza z West Hills, którą Barańczak dodatkowo cyzeluje, zbliża do miary Whitmanowskiej.

Możemy więc uznać, że Ginsberg, którego Barańczak ceni, czy też po prostu toleruje, to Ginsberg zakładający maski, markujący chwyty mistrza, powściągający swą „skowyczącą” poetykę na rzecz spłacenia długu wobec dykcji patrona. Trudno wskazać, czy większą wagę tłumacz przywiązuje do ratowania pierwotnego 
kształtu poetyckiego dialogu pokoleń, precyzyjnego odtworzenia sytuacji poetyckiej, czy do intertekstualnego układu strof poematu i ich „oddechowej” rytmizacji. Dominantą semantyczną w Supermarkecie... pozostaje bowiem patronat Whitmanowski, z całym poetyckim rekwizytorium wynikającym z tego tribute to, spisanego przez Ginsberga w kalifornijskim Berkeley rok przed premierą Howl and the other poems.

\section{Bibliografia}

Barańczak Stanisław (1994), Ocalone w ttumaczeniu, a5, Poznań.

Barańczak Stanisław (1998), Supermarket $w$ Kalifonii, w: tegoż, Od Walta

Whitmana do Boba Dylana. Antologia poezji amerykańskiej,

Wydawnictwo Literackie, Warszawa, s. 229-230.

Barańczak Stanisław (2001), Wstęp: Po obu stronach lustra, w: James

Merrill, Wybór poezji, przeł. Stanisław Barańczak, a5, Poznań, s. 9-18. Burns Glen (1983), Great Poets Howl: A Study of Allen's Ginsberg's Poetry, 1943-1955, Peter Lang, New York [USA].

Fone Byrne R.S. (2001), The Columbia Anthology of Gay Literature,

Columbia University Press, Columbia [USA].

Ginsber Allen (1959), Notes Written on Finally Recording ,Howl', „Evergreen Review”, nr 10, s. 132-135.

Ginsberg Allen (2009), A Supermarket in California, w: tegoż, Collected

Poems 1947-1997, Penguin Books, London [Wielka Brytania], s. 144.

Jarniewicz Jerzy (2018), Ttumacz między innymi. Szkice o przekładach,

językach i literaturze, Ossolineum, Wrocław.

Morgan Bill (2006), I Celebrate Myself: The Somewhat Private Life of Allen Ginsberg, Penguin Books, London [Wielka Brytania].

Pfeiler Martina (2003), Sounds of Poetry. Contemporary American

Performance Poets, Gunter Narr Verlag, Tübingen [Niemcy].

Sommer Piotr (2018), Po stykach, wвpicak, Poznań.

Whitman Walt (1992), Poets to Come, w: tegoż, Pieśn o sobie / Song of Myself, tłum. Andrzej Szuba, Wydawnictwo Literackie, Kraków, S. 28-29.

\section{Oskar Meller}

\section{Barańczak's Ginsberg. On the story of one (and only) translation}

The article is an analysis of the translation of the poem A Supermarket in California (Supermarket $w$ Kaliforni), the only poem by Allen Ginsberg 
translated by Stanisław Barańczak. In the critical works of the author of Facial Corrections (Korekta twarzy) the beatnik's poetics is contrasted with the poetry of Robert Frost and James Merill - writers crucially important to the translator. Despite this, A Supermarket... enriched Barańczak's anthology of American Poetry published in 1998. The translator's key choice appears to be the use of a conversational idiom, placing the poem opposite the 'howling' diction from the flagship poems of the author of Howl. The testaments of a dialogue with tradition is what Barańczak seeks in it; he is most interested in the formal and semantic bows to the father of American poetry. What Barańczak makes the semantic dominant is, rather than the structure of the text or the images evoked in it, Whitman's patronage with all its consequences.

Keywords: Barańczak; Ginsberg; Whitman; translation; supermarket; California.

Oskar Meller - doktorant, krytyk literacki. Obecnie przygotowuje rozprawę doktorską dotyczącą wpływów języka poetyckiego Tomasza Pułki na dykcję jego pokoleniowych rówieśników. Interesuje się polską poezją najnowszą, xx-wieczną poezją amerykańską, a także reprezentacjami nurtu Bildungsroman w powieści europejskiej. Adres e-mail: oskar.meller@uwr.edu.pl. 